\title{
Studies in Inductive Logic and Probability
}

VOLUME I 



\section{Studies in Inductive \\ Logic and Probability}

VOLUME I

Rudolf Carnap and Richard C. Jeffrey

EDITORS

UNIVERSITY OF CALIFORNIA PRESS

BERKELEY · LOS ANGELES · LONDON · 1971 
University of California Press

Berkeley and Los Angeles

University of California Press, Ltd.

London, England

Copyright (C) 1971 by The Regents of the University of California

ISBN: 0-520-01866-4

Library of Congress Catalog Card Number: 77-136025

Printed in the United States of America

Designed by Dave Comstock 